\title{
DNA fingerprinting with homologous multilocus probes and search for DNA markers associated with yield attributes in silkworm, Bombyx mori
}

\author{
Balakathiresan N. SETHURAMAN, Thampiyath P. MOHANDAS and Shankar N. CHATTERJEE*
}

SeriBiotech Lab, Central Silk Board, Campus-Kodathi, Bangalore 560035, Karnataka, India

Key words. Bombyx mori, DNA fingerprinting, multilocus probes, Restriction Fragment Length Polymorphism, RFLP

\begin{abstract}
RFLP clones harbouring multi-copy DNA sequences were isolated from the Pst I sub-genomic library of the indigenous silkworm race, Nistari, and were used for DNA fingerprinting studies in 13 stocks of silkworm, Bombyx mori L. Six multilocus probes produced 180 RFLP markers that showed a high level (98\%) of polymorphism and are highly useful in molecular mapping, genotype characterization and marker assisted selection (MAS). The dendrogram derived from UPGMA analysis clearly divides the 13 silkworm stocks into two major clusters: high- and low-yield stocks. Furthermore, adopting multiple regression analyses, the RFLP marker(s) associated with characters of economic importance were identified, a first of its kind for any species of insect of commercial importance. The results obtained create an opportunity of using germplasm stocks directly for isolating specific RFLP band(s) and use it for MAS in breeding programs.
\end{abstract}

\section{INTRODUCTION}

The Restriction Fragment Length Polymorphism (RFLP) profiling (Botstein et al., 1980; Tanksley et al., 1989) proved to be a very important technique for identifying genotypic differences. It is applied to both plant and animal systems (Jeffreys et al., 1985, 1991; Miller \& Tanksley, 1990; Song et al., 1990; Jung et al., 1993), especially because of their reproducibility (Paull et al., 1998). The relationship between different species as well as other taxonomic issues has been examined with improved methodologies for generating RFLP profiles (Virk et al., 1996; Salimath et al., 1995; Lu et al., 1996). The polymorphic DNA markers also helped in the construction of a linkage map for various plant (Tanksley et al., 1992; Paterson et al., 1995) and insect species (O'Brien, 1993) including the silkworm, Bombyx mori (Shi et al., 1995). The banded krait minisatellite (Bkm-2 (8)) has also been used successfully as a probe in generating highly polymorphic RFLP profiles for several stocks of $B$. mori (Nagaraju et al., 1995). Probes were also developed from homologous genomes by the digestion of genomic DNA with specific restriction enzymes for identification of clones (Jung et al., 1993). However, such a system has not been utilised for assessing genetic variability among the different stocks and breeds of $B$. mori. The present report is based on the result of such an attempt. As indicated elsewhere, the system is based mainly on the generation of multi-copy DNA sequence probes (Sulaiman et al., 1995).

B. mori, commercially, contributes more than $90 \%$ to total silk production (Currie, 1996) and is represented by a large number of stocks having a wide range of yield potential (Chatterjee \& Datta, 1992; Chatterjee, 1993). Conventional studies were made to understand the genetics of yield components, but until now, no attempt has been made to identify specific DNA marker(s) contributing to the wide variability in yield potential. Furthermore, the low yielding silkworm stocks are less susceptible to diseases and abiotic stresses, while the high yielding breeds and hybrids need strict disease management and control of abiotic factors (Goldsmith, 1991; Chatterjee et al., 1993) for fuller realization of yield potential. Indian silk-cocoon producers include a large section of small and marginal farmers, for whom strict disease management and high input of fertiliser and disinfectants are a well-defined economic constraint. Thus, molecular analysis of these yield components and identification of DNA markers associated with high germ-load tolerance and high yield potential are of great significance for establishing work on directional molecular breeding of the silkworm. The relevance of DNA markers for molecular breeding and conventional breeding has been extensively highlighted elsewhere (Mitra et al., 1999), and is of great relevance for India and other countries of the third world practicing sericulture.

The identification of specific DNA markers associated with such attributes of economic importance, including that of disease resistance, is in itself an important issue. One of the approaches that has been adopted by Michaelmore et al. (1991) was the generation of bulk-segregants based on specific yield component or disease resistance/susceptibility among the $F_{2}$ population. The $F_{2}$ population is raised from the cross between two stocks, divergent for the specific character under study. Another approach is to establish a similar association on the basis of correlation between DNA profiles and specific phenotypic characters (Virk et al., 1996; Yonash et al., 2000). The present report is based on the result of analyses fol-

\footnotetext{
* Corresponding author. SeriBiotech Laboratory, Central Silk Board, Campus-Kodathi, Bangalore - 560 035, India; e-mail: chatterjeesn2002@yahoo.co.in; tel: 91-80-8440651-653, fax: 91-80-8439597.
} 
TABLE 1. List of thirteen silkworm stocks, information on their parentage and country of origin.

\begin{tabular}{llll}
\hline Stock & Parentage & Country & Reference \\
\hline BBE-CHI & Unknown (Hu204) & China & Reddy et al., 1999 \\
BBI-0095 & (N122.C110).(N124.C124) & Indian breed & Chatterjee, 1993 \\
BBE-JAP & Unknown (NB1) & Japanese breed & Chatterjee \& Datta, 1992 \\
BBI-0082 & Kinshu-Showa & Indian breed & Thangavelu et al., 1997 \\
BBI-0081 & (N124.C124). (Kokko.Seihaku) & Indian breed & Thangavelu et al., 1997 \\
BBI-0044 & (N124.C124). (Kokko.Seihaku) & Indian breed & Thangavelu et al., 1997 \\
BME-0005 & Shi x Nichi (C'Nichi) & Indian race & Chatterjee \& Datta,1992; \\
& & & Ghosh, 1949 \\
BME-0013 & Unknown (Guangnong) & China & Chatterjee et al., 1993a \\
BMI-0003 & Unknown (Moria of Assam) & Indian race & Chatterjee \& Datta, 1992 \\
BMI-0017 & Unknown (Nistari of Bengal) & Indian race & Chatterjee \& Datta, 1992 \\
BMI-0001 & Unknown (Mysore, Karnataka) & Indian race & Chatterjee \& Datta, 1992 \\
BME-0052 & Unknown (Diazo) & Chinese race & Chatterjee et al., 1993a \\
BMI-0002 & Unknown (Sarupat of Assam) & Indian race & Chatterjee \& Datta, 1992 \\
\hline
\end{tabular}

$\mathrm{BB}=$ Bomby $x$ bivoltine; $\mathrm{BM}=$ Bomby $x$ multivoltine; $\mathrm{I}=$ indigenous; $\mathrm{E}=$ exotic CHI $=$ Chinese; $\mathrm{JAP}=$ Japanese.

lowing the second approach and is first of its kind for any species of insect having economic importance.

\section{MATERIALS AND METHODS}

\section{Silkworm stocks}

The present study was based on thirteen races and breeds of Indian, Chinese and Japanese origin (Table 1), and these stocks are maintained in the lab for more than 10 generations. The mean estimates of ten yield components and the status of voltinism for the thirteen stocks utilized, given in Table 2, are taken from published manual of Central Silkworm Germplasm Resource Centre (Thangavelu et al., 1997).

\section{DNA extraction}

The genomic DNA was isolated from posterior silk glands of a minimum of ten four days old, fifth instar larvae for each of the thirteen stocks mentioned earlier. To study inheritance, the genomic DNA was extracted from individual moths of BMI0017 (low yielding Indian race) and BBE-JAP (high yielding Japanese breed) as well as their $F_{1}$ hybrid progeny. The silkglands or the moths were crushed in liquid nitrogen, subjected to lysis in the presence of proteinase- $\mathrm{K}$ at $37^{\circ} \mathrm{C}$ and followed by the normal method of phenol-chloroform extraction with ethanol precipitation. The DNA initially obtained was re-extracted in the same way after RNase A treatment and finally dissolved in $10 \mathrm{mM}$ TE buffer [Tris- $\mathrm{Na}_{2}$ EDTA (ethylene-diamine-tetra-acetic acid, di-sodium salt)].

TABLE 2. Average estimates (Thangavelu et al., 1997) of yield components of thirteen silkworm stocks used for generating RFLP profiles.

\begin{tabular}{|c|c|c|c|c|c|c|c|c|c|c|c|c|}
\hline Stock & Origin & $\begin{array}{c}\text { EGG } \\
(\mathrm{No})\end{array}$ & $\begin{array}{c}\text { TLD } \\
\text { (Hrs) }\end{array}$ & $\begin{array}{l}\text { VLD } \\
\text { (Hrs) }\end{array}$ & $\begin{array}{l}\text { LWT } \\
(\mathrm{gm})\end{array}$ & $\begin{array}{l}\text { PWT } \\
(\mathrm{gm})\end{array}$ & $\begin{array}{l}\text { CWT } \\
(\mathrm{gm})\end{array}$ & $\begin{array}{l}\text { SHWT } \\
\text { (cg) }\end{array}$ & $\begin{array}{c}\text { SR } \\
(\%)\end{array}$ & $\begin{array}{l}\text { YLD } \\
\text { (No) }\end{array}$ & $\begin{array}{l}\text { YLD } \\
\text { WT } \\
\text { (kg) }\end{array}$ & VOLT \\
\hline BBE-CHI & Chinese & 481 & 590 & 138 & 2.77 & 1.07 & 1.29 & 0.22 & 15.8 & 6303 & 8.03 & $\mathrm{D}$ \\
\hline BME-0013 & Chinese & 417 & 558 & 135 & 2.43 & 0.96 & 1.13 & 0.17 & 14.6 & 7592 & 8.57 & ND \\
\hline BME-0052 & Chinese & 393 & 564 & 162 & 2.17 & 0.83 & 0.96 & 0.13 & 13.8 & 7062 & 6.72 & $\mathrm{D}$ \\
\hline BME-0005 & $\operatorname{Indian}(1)^{*}$ & 397 & 539 & 112 & 2.10 & 0.88 & 1.00 & 0.12 & 12.0 & 7923 & 8.11 & ND \\
\hline BMI-0003 & Indian(1) & 388 & 564 & 145 & 2.69 & 0.97 & 1.13 & 0.16 & 14.7 & 8045 & 9.72 & ND \\
\hline BMI-0017 & Indian(1) & 381 & 557 & 143 & 2.10 & 0.89 & 1.02 & 0.13 & 13.0 & 7972 & 7.72 & ND \\
\hline BMI-0001 & Indian(1) & 457 & 626 & 186 & 1.82 & 0.86 & 1.00 & 0.14 & 14.1 & 7410 & 7.15 & ND \\
\hline BMI-0002 & Indian(1) & 405 & 569 & 149 & 2.52 & 0.99 & 1.16 & 0.17 & 14.9 & 7717 & 9.02 & ND \\
\hline BBI-0095 & $\operatorname{Indian}(2)^{*}$ & 412 & 602 & 174 & 3.52 & 1.25 & 1.50 & 0.25 & 16.8 & 8246 & 11.92 & $\mathrm{D}$ \\
\hline BBI-0082 & Indian(2) & 424 & 599 & 165 & 3.42 & 1.28 & 1.56 & 0.28 & 18.0 & 8038 & 11.59 & $\mathrm{D}$ \\
\hline BBI-0081 & Indian(2) & 395 & 600 & 166 & 3.61 & 1.30 & 1.57 & 0.27 & 17.2 & 8292 & 13.42 & $\mathrm{D}$ \\
\hline BBI-0044 & Indian(2) & 479 & 646 & 206 & 3.54 & 1.47 & 1.82 & 0.36 & 19.6 & 8342 & 16.12 & $\mathrm{D}$ \\
\hline BBE-JAP & Japanese & 524 & 600 & 167 & 3.54 & 1.69 & 1.95 & 0.26 & 17.3 & 6198 & 9.98 & $\mathrm{D}$ \\
\hline \multicolumn{2}{|c|}{ Standard deviation } & 44.2 & 30.4 & 24.3 & 0.66 & 0.27 & 0.33 & 0.07 & 2.16 & 710.5 & 2.73 & \\
\hline
\end{tabular}

*(1) and (2) indicate Indian race and Indian breed, respectively.

EGGNO = mean number of eggs laid by one mother moth; TLD = total larval duration; VLD = duration of fifth instar;

LWT, PWT, CWT, and SHWT denote weight of single matured larva, pupa, cocoon, and cocoon shell, respectively;

$\mathrm{SR} \%=$ ratio of weight of shell to the weight of cocoon; YLDNO and YLDWT $=$ number of cocoons realized $/ 10,000$ larvae reared and their weight. VOLT $=$ voltinism; ND and D denote non-diapause and diapause, respectively. 

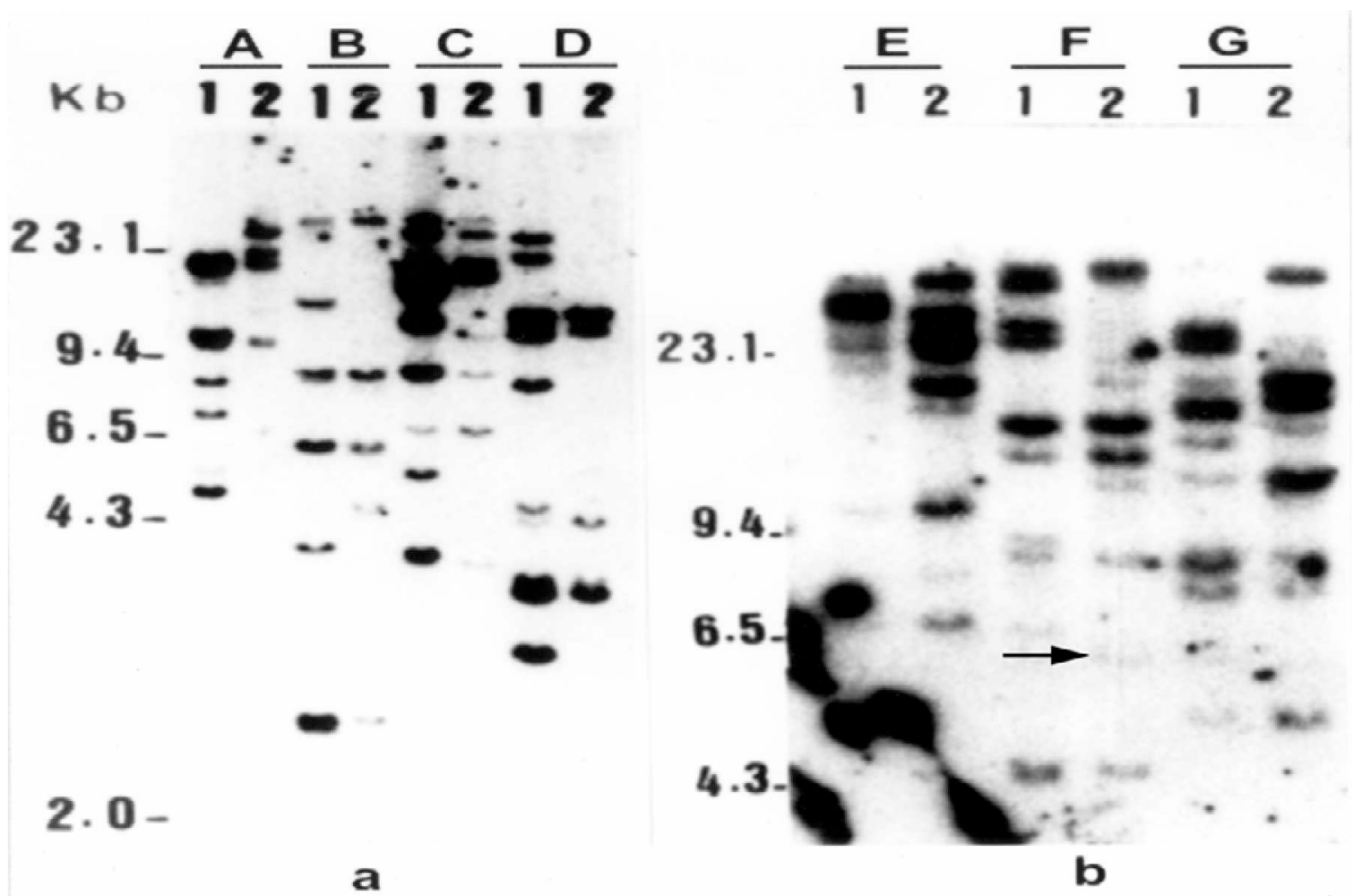

Fig. 1. Polymorphism detected by multilocus probe, $\mathrm{pBmN}$ 138(a) \& 319(b) on two selected divergent stocks, BMI-0017 (1) and BBE-JAP (2), when digested with different restriction enzymes, Bam HI (A), Eco RI (B\&E), Eco RV (C\&F), and Hind III (D\&G). The arrow marks the position of bands not properly labeled in the autoradiogram, but clearly visible in Fig $2 \mathrm{~b}$.

\section{DNA probes}

A size selected $(0.5-2 \mathrm{~kb})$ Pst I silkworm genomic library was prepared in the $\mathrm{pUC}_{18}$ using genomic DNA from BME0017 (Nistari), one of the oldest Indian races of silkworm. Multiple copy recombinant clones were selected by colony hybridization using ${ }^{32} \mathrm{P}$-labelled total silkworm genomic DNA as a probe (Sulaiman et al., 1995). For Southern hybridization, probes with insert length varying between 0.8 to $1.8 \mathrm{~kb}$, were labeled with $\alpha^{32} \mathrm{P}$ CTP using a random primer labeling kit (Amersham Int. Buckinghamshire, UK) (Sambrook et al., 1989).

\section{Restriction digestion, electrophoresis and Southern hybridi-} zation

10-12 $\mu \mathrm{g}$ of DNA per sample was digested to completion with different restriction enzymes (New England Biolabs, Hertfordshire, England). Four restriction endonucleases such as Bam HI, Eco RI, Eco RV and Hind III were used for the DNA fingerprinting studies. Digested DNA was separated by electrophoresis on $0.8 \%$ agarose gel in $1 \mathrm{X}$ TAE (40mM Tris, $20 \mathrm{mM}$ acetate and $1 \mathrm{mM}$ EDTA) buffer. The gel fractionated DNA samples were vacuum blotted to a Hybond-N Nylon membrane (Amersham Int., Buckinghamshire, UK). Subsequent to baking at $80^{\circ} \mathrm{C}$ for $2 \mathrm{~h}$, the membranes were hybridized (Sambrook et al., 1989) at $65^{\circ} \mathrm{C}$ for $16 \mathrm{~h}$, and washed several times at $65^{\circ} \mathrm{C}$ in descending concentration of $2.0 \mathrm{X}$ to $0.1 \mathrm{X} \mathrm{SSC}$ (sodium chloride/sodium citrate buffer) containing $0.1 \%$ SDS (sodium dodecyl sulphate). Subsequently, the blots were exposed with Kodak X-ray film with intensifying screens for $1-3$ days at $-70^{\circ} \mathrm{C}$.

\section{Data analysis}

Binary scoring ( 0 and 1$)$ was done from RFLP profiles observed for 13 different silkworm stocks using six different probes in autoradiograms. For all DNA profiles, only distinguishable fragments greater than $2.0 \mathrm{~kb}$ were scored. Pairwise comparison of DNA fingerprint lanes was done only within a gel.

Estimation of similarity index. For clustering, the similarity index (S) was calculated after Nei and Li (1979), as the fraction of shared fragments between pairs of silkworm stocks. For silkworm stocks, $\mathrm{x}$ and $\mathrm{y}, \mathrm{S}=2 \mathrm{Nxy} / \mathrm{Nx}+\mathrm{Ny}$ where $\mathrm{Nxy}$ was the number of common fragments in the two silkworm stocks, while $\mathrm{Nx}$ and $\mathrm{Ny}$ are the number of fragments scored in stocks $\mathrm{x}$ and $\mathrm{y}$, respectively. For the thirteen different genotypes, $\mathrm{S}$ was converted to a genetic distance as $\mathrm{D}=1-\mathrm{S}$. The dendrogram was constructed using the "UPGMA" (Unweighted pair-group method using arithmetic average) method in the PHYLIP programme (Felsenstein, 1989).

Correlation and multiple regression analysis. All DNA bands scored were considered as independent variables while yield components of silkworm stocks were taken as dependent variables. First, Pearson correlation coefficients were determined for all DNA markers. DNA markers showing positive correlation with yield components were identified and analyzed using multiple regression analyses. The provision of stepwise multiple regression analysis available with SPSS 10.0 program was used with $\geq 0.45$ and $\leq 0.099$ as F-value to enter and remove, respectively. 


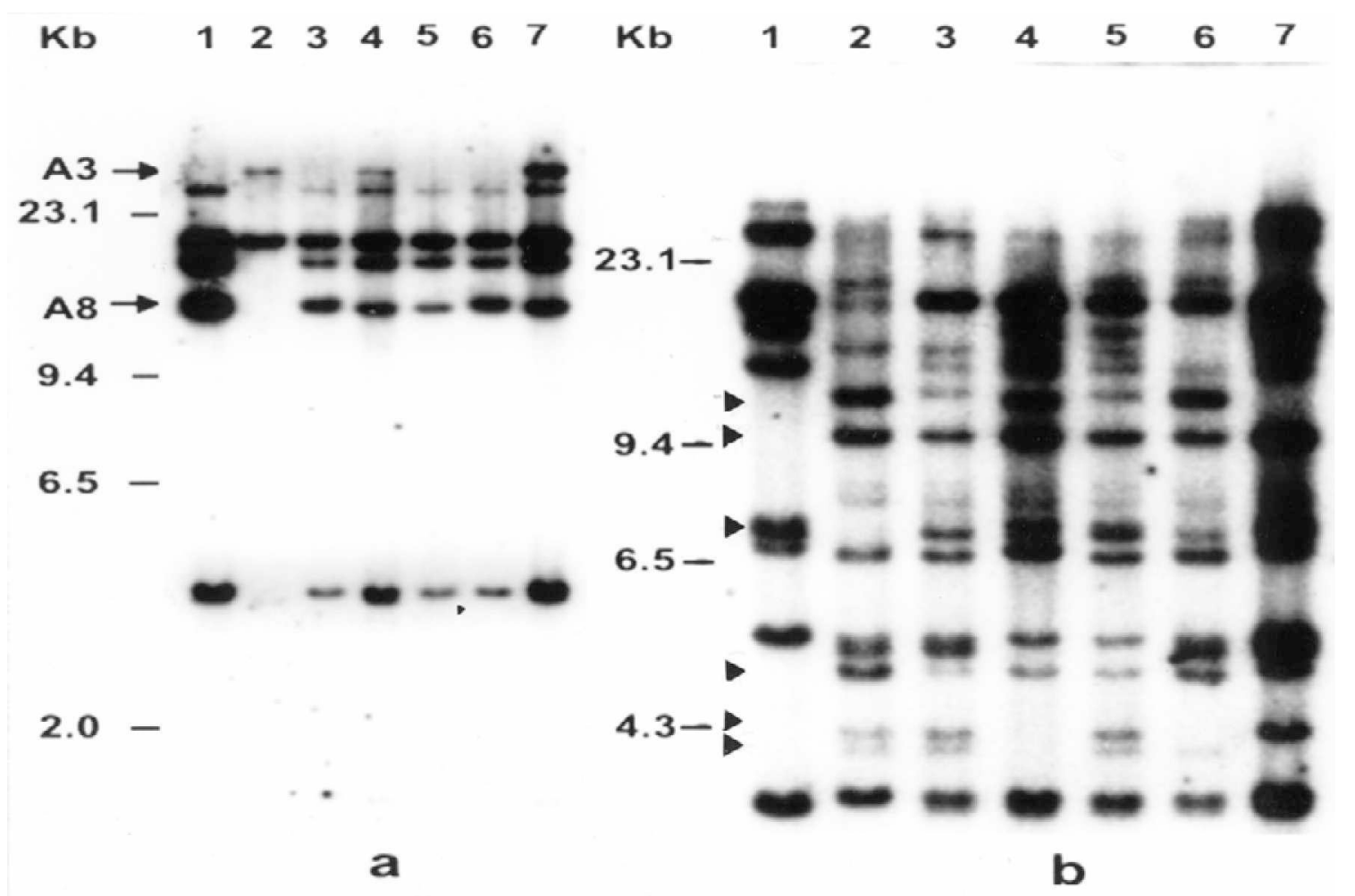

Fig. 2. The hybridization pattern of Eco RV digested DNA from parents, BMI-0017 (lane-1) and BBE-JAP (lane-2) silkworm stocks and their $\mathbf{F}_{1}$ offspring (lanes 3-7) with the multilocus probe, $\mathrm{p} B m \mathrm{~N} 138$. a - bands $\mathrm{A} 13$ and A8 marked with arrows are two of the eight bands projected in Table 6 for their significant association with LWT and SR $\%$, respectively; $b$ - the arrow-heads point out the polymorphic bands between the two parents and illustrate the detection of homo- or heterozygous status from the segregation of the marker(s) in $\mathbf{F}_{1}$ individuals. The duplex- band of $\sim 5.0 \mathrm{~kb}$ in lane 2 appears very prominent in comparison to the faint band in lane-2 of $\mathrm{F}$ in Fig. 1b.

\section{RESULTS}

\section{DNA fingerprinting analysis}

A total of 1056 recombinant plasmids were obtained from the partial genomic library developed from Pst I digest of silkworm genomic DNA. On dot blot screening, 245 recombinant plasmids showing signal of moderate intensity were selected as putative multiple copy clones. Of these, twenty-five clones were randomly selected and screened for their polymorphism on two selected divergent silkworm stocks, BMI-0017 (low yielding) and BBE-JAP (high yielding). Four restriction enzymes, Bam HI, Eco RI, Eco RV and Hind III were used for initial screening (Fig. 1a, b). Among the above four restriction enzymes, Eco RI and Eco RV produced maximum polymorphism $(85 \%)$ when compared to Bam HI or Hind III $(60 \%)$. Southern hybridization showed that the cloned fragments of all 25 recombinant plasmids were distributed in the size range of 2 to $23 \mathrm{~Kb}$ (Fig.1a,b). However, six of these $\mathrm{p} B m \mathrm{~N}$ clones (138(A), 319(B), 445(C), 803(D), 948(E), and 966(F)), with an insert size varying from 0.8 to $1.8 \mathrm{~kb}$ and a high level of polymorphic pattern between these BMI-0017 and BBE-JAP stocks, were subsequently selected for fingerprint analysis in the thirteen silkworm stocks (Fig. 3a,b).
The six multilocus probes produced 180 RFLP markers across the 13 silkworm stocks and of these, 38 fragments were not present in more than one stock. The number of unique fragments was found to be highest for BME-0005, while, no unique fragment could be detected for BBI0081 and BBI0082. Inheritance pattern for the few selected multilocus probes such as $\mathrm{p} B m \mathrm{~N} 138,319,803$ and 966 were studied in the $\mathrm{F}_{1}$ progeny of BMI-0017 X BBE-JAP cross (Fig. 2a,b). The pattern presented in Fig. 2a,b, clearly substantiates the inheritance of the RFLP markers from parents to offspring. From the profiles of $F_{1}$ individuals and their parents, presented in Fig 2a,b, it is also evident that before planning to utilize specific markers for MAS program, it is possible to determine whether a marker in a parent is homo- or heterozygous. For example, the presence of the marker A-8 in all $F_{1}$ individuals suggests that it is homozygous in the parent- 1 . On the other hand, the absence of the band A-3 in three of the five $F_{1}$ individuals tested indicated it to be in heterozygous condition in parent-2. Likewise, the first two markers at the top of Fig $2 b$ (indicated with arrowhead), could be detected in all the offspring, showing its homozygous status in parent 2 because this is the only parent possessing these markers. The distribution of the last two marked fragments exhibits their heterozygous status in 


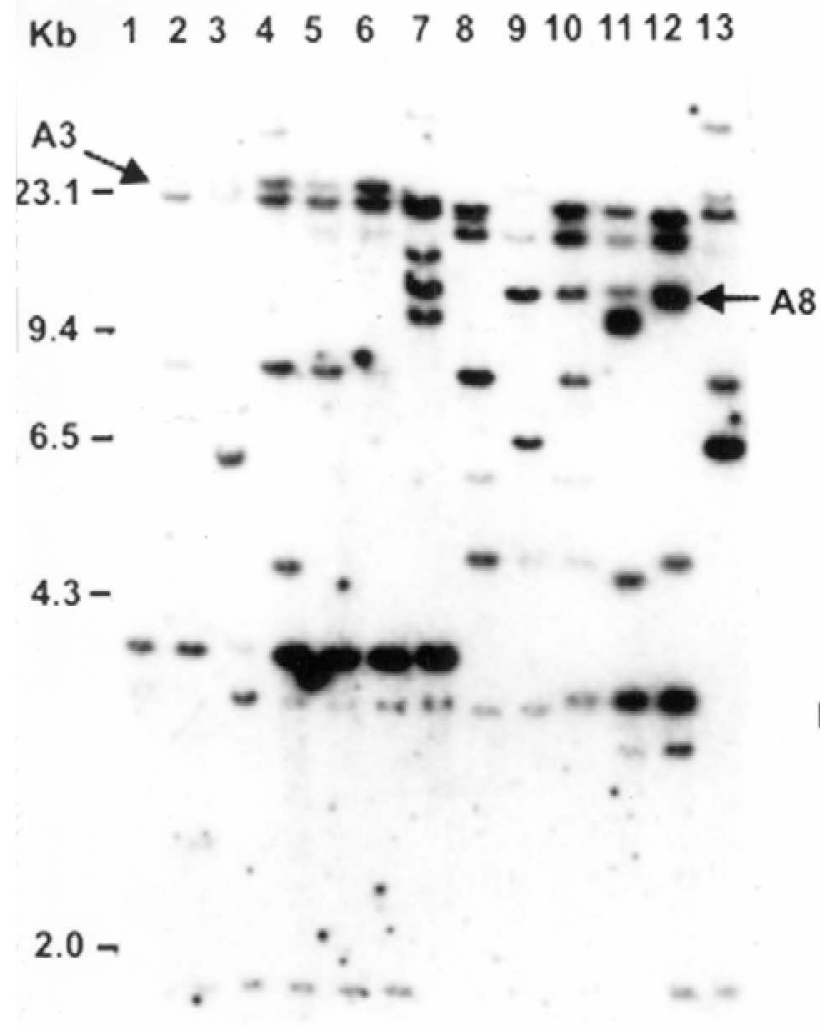

a

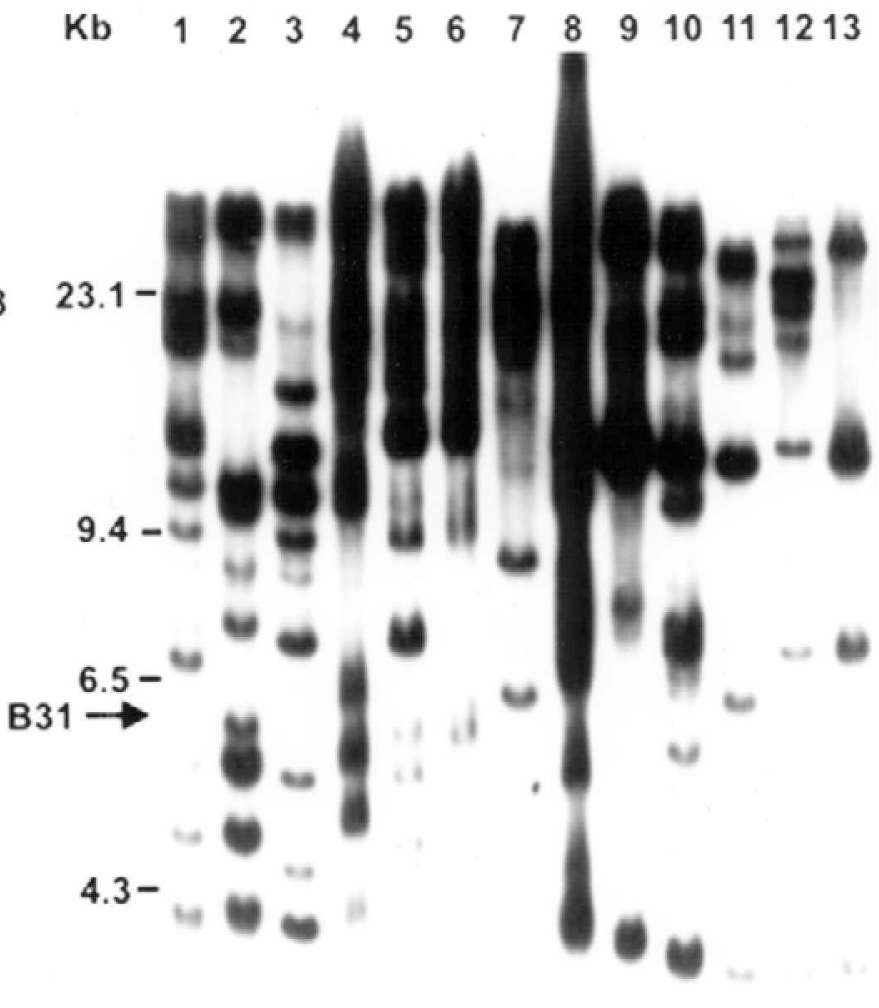

b

Fig. 3. Polymorphism generated with multilocus probes, $\mathrm{p} B m \mathrm{~N} 138(\mathrm{a})$ and 319 (b) using pooled template DNA of 13 silkworm stocks, digested with Eco RV. Lane 1-13 represents profiles for BBE-CHI, BBI-0095, BBE-JAP, BBI-0082, BBI-0081, BBI-0044, BME-0005, BME-0013, BMI-0003, BMI-0017, BMI-0001, BME-0052, and BMI-0002, respectively. The three RFLP-markers, A3, $\mathrm{A} 8$, and B31 (arrows), designate the bands selected for their significant association with LWT, SR \%, and YLDWT, respectively (Tables 5 and 6).

parent 2. However, mention should be made of the very prominent duplex-band of $\sim 5.0 \mathrm{~kb}$ in lane 2 of Fig. $2 \mathrm{~b}$. The band in the same position in Fig. $1 \mathrm{~b}$ (lane 2 of F) appears very faint, possibly due to a bleaching effect in the autoradiogram as evident from black smear in the left corner. However, it may be also noted that DNA template used for work presented in Fig. 1 is from a minimum of 10 individuals, isolated en-masse, while that in Fig. 2 is from a single parent of the particular cross.

\section{Genetic variation}

Each hybridising fragment from the DNA fingerprint for 13 silkworm stocks (Fig. 3a,b) was scored as a piece of independent data and a genetic similarity index (S) for each pair of silkworm stocks was calculated (Table 3), which revealed the similarity index ranging from 0.23 to 0.75 with the average of 0.40 . It is also of interest to note that the highest similarity was found between the Chinese stock, BME-0052, and the Indian stock, BMI-0002.

\section{Genetic relationship among silkworm stocks}

The dendrogram derived from UPGMA analysis clearly depicts the presence of two major clusters (Fig. 4). The
Cluster-A includes all the five Indian stocks of low yield potentials (Table 2) and two Chinese stocks, almost of similar yield status. The Cluster-B includes all improved Indian breeds and one Chinese stock, BBE-CHI, of medium yield of $8.03 \mathrm{~kg}$ cocoons $/ 100$ broods. The dendrogram further reveals that BME-0005 enters the cluster combination at the eleventh (last) step of agglomeration while in the preceding step, cluster-pair of BBI-0095 and BBE-CHI, joined the small sub-cluster of BBI-0044: BBI-0081: BBI-0082: BBE-JAP.

\section{Association between DNA markers and yield components}

Correlation analysis between 180 alleles and ten yield components revealed significant ( $P=0.05$ and 0.01$)$ association for 70 alleles, and the r-values ranged from a minimum of 0.555 to 0.811 . The results (Table 4) revealed that 18 alleles bear significant correlation with not more than one yield trait. Eleven of these alleles, A2, A7, B8, B18, C6, D20, E6, E7, E11, E14, and E18 showed significant correlation with VLD only. C7, E23, E27, and D10 were associated with EGGNO, TLD, LWT, and YLDWT, respectively. The remaining three, A12, 


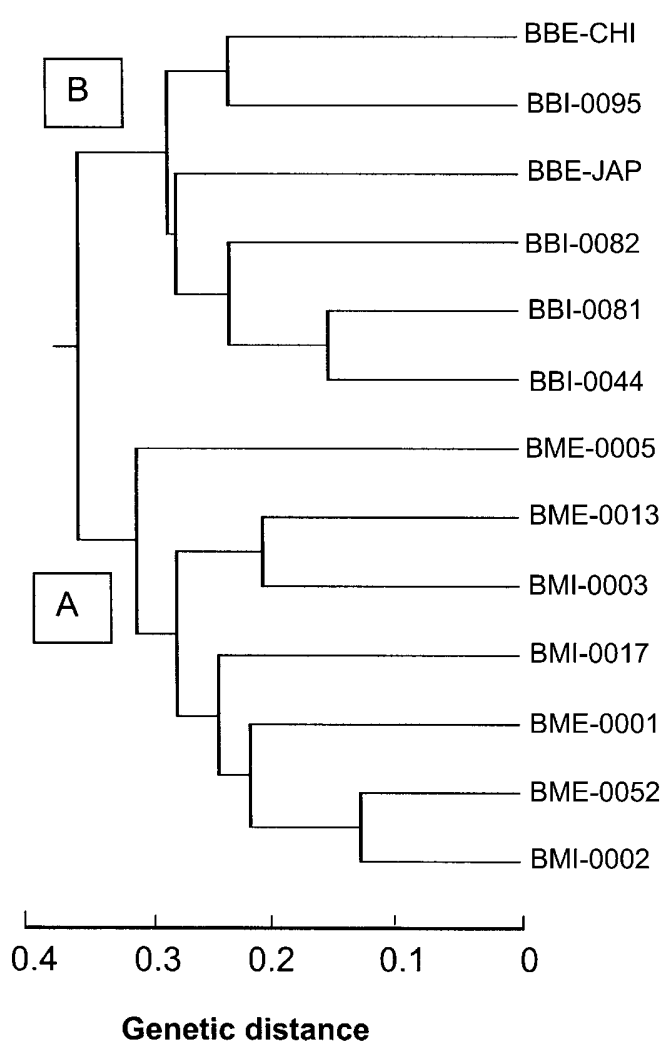

Fig. 4. The dendrogram based on RFLP markers illustrating the classification of silkworm stocks into two well defined subclusters, comprising of stocks having low (sub-cluster-A) and high yield (sub-cluster-B) potential.

B16 and F20 were correlated to YLDNO alone. However, no fragment showed significant correlation, either negative or positive, with all the yield parameters. It is of further interest to note that, except in the case of EGGNO, the fragment showing negative correlation were more in number than those revealing positive correlation, with respect to any dependent variable.

Results of stepwise regression analyses with the selected 70 fragments and eleven dependent variables (ten yield components and voltinism) are presented in Table 5. It is evident that within the limit fixed for F-to enter and
F-to remove, the analysis selected only three fragments for EGGNO, CWT and SHWT while for TLD, the number of alleles contributing positive effect is 9 , which is the maximum. Some fragments have significant contributory effect in the formation of regression equation for more than one character. For example, D5 was selected for EGGNO, TLD and VLD while F24 appeared significant for TLD and LWT. Further, the relative importance of some bands differs for different yield components, e.g., D5 was selected at step-2 for EGGNO and TLD, while it was selected at the step-1 for VLD. Summarizing the data in Table 5, it may be said that 27 fragments are being selected out of 70 fragments analyzed for multiple regression, three of which are marked in Fig. 3a,b.

To test the efficacy of the selection of fragments through MRA, the status of marker(s) selected at the first step of stepwise regression in the thirteen silkworm stocks was examined by t-test (Table 6). Result for all the yield components, except EGGNO, show that the group mean for those stocks where the band is absent significantly differs from the group mean for those stocks where the band is present.

\section{DISCUSSION}

\section{Level of polymorphism}

Shi et al. (1995) showed that the silkworm genome with comparatively higher GC content can produce high polymorphism when restriction enzymes with six base pair recognition sequences are used. The presented results corroborate the above finding. Similar level of polymorphism was also observed in plants (Neuhusen, 1992; Bark \& Havey, 1995) and in insects (Musca domestica; Blanchetot, 1991).

The level of polymorphism (98\%) presently realized is higher than that realised with various PCR based markers such as RAPD (94\%; Nagaraja \& Nagaraju, 1995), ISSR (86\%; Reddy et al., 1999b) and SSR (77\%; Reddy et al., $1999 \mathrm{a})$ or that realised with the use of $\mathrm{Bkm}-2(8)$ probe (Nagaraju et al., 1995). Landry et al. (1987) comparing various sources of probes for their efficiency in detecting RFLP in lettuce concluded that an increased detection of polymorphism in multiple copy sequences could be the

TABLE 3. Genetic similarity index (S) between pairs of silkworm genotypes.

\begin{tabular}{|c|c|c|c|c|c|c|c|c|c|c|c|c|}
\hline & $\begin{array}{l}\text { BBI- } \\
0095\end{array}$ & $\begin{array}{l}\text { BBE- } \\
\text { JAP }\end{array}$ & $\begin{array}{l}\text { BBI- } \\
0082\end{array}$ & $\begin{array}{l}\text { BBI- } \\
0081\end{array}$ & $\begin{array}{l}\text { BBI- } \\
0044\end{array}$ & $\begin{array}{l}\text { BME- } \\
0005\end{array}$ & $\begin{array}{l}\text { BME- } \\
0013\end{array}$ & $\begin{array}{l}\text { BMI- } \\
0003\end{array}$ & $\begin{array}{l}\text { BMI- } \\
0017\end{array}$ & $\begin{array}{l}\text { BMI-- } \\
0001\end{array}$ & $\begin{array}{l}\text { BME- } \\
0052\end{array}$ & $\begin{array}{l}\text { BMI- } \\
0002\end{array}$ \\
\hline BBE-CHI & 0.553 & 0.444 & 0.396 & 0.455 & 0.468 & 0.328 & 0.333 & 0.333 & 0.367 & 0.239 & 0.259 & 0.207 \\
\hline BBI-0095 & - & 0.435 & 0.450 & 0.518 & 0.487 & 0.320 & 0.239 & 0.261 & 0.269 & 0.237 & 0.260 & 0.260 \\
\hline BBE-JAP & & - & 0.426 & 0.505 & 0.478 & 0.421 & 0.377 & 0.358 & 0.373 & 0.280 & 0.404 & 0.316 \\
\hline BBI-0082 & & & - & 0.529 & 0.575 & 0.392 & 0.277 & 0.319 & 0.283 & 0.232 & 0.294 & 0.333 \\
\hline BBI-0081 & & & & - & 0.706 & 0.393 & 0.323 & 0.323 & 0.324 & 0.300 & 0.374 & 0.393 \\
\hline BBI-0044 & & & & & - & 0.400 & 0.348 & 0.391 & 0.308 & 0.280 & 0.340 & 0.360 \\
\hline BME-0005 & & & & & & - & 0.404 & 0.456 & 0.365 & 0.365 & 0.443 & 0.426 \\
\hline BME-0013 & & & & & & & - & 0.604 & 0.508 & 0.411 & 0.439 & 0.404 \\
\hline BMI-0003 & & & & & & & & - & 0.525 & 0.449 & 0.491 & 0.526 \\
\hline BMI-0017 & & & & & & & & & - & 0.538 & 0.556 & 0.508 \\
\hline BMI--0001 & & & & & & & & & & - & 0.591 & 0.574 \\
\hline BME-0052 & & & & & & & & & & & - & 0.754 \\
\hline
\end{tabular}


TABLE 4. List of RFLP markers showing significant positive and negative correlation with selected yield parameters.

\begin{tabular}{|c|c|c|}
\hline Yield trait & Positively correlated alleles & Negatively correlated alleles \\
\hline EGGNO & $\begin{array}{l}\text { A. } 14, \text { B. } 12, \text { B. } 22, \text { C. } 3, \text { C } .12, \text { C. } 25, \text { D. } 25 \text {, } \\
\text { D. } 26, \text { E. } 25, \text { F. } 14\end{array}$ & C.7, D.12, F.22 \\
\hline TLD & B. 31 , C. 5 , C. 12 , C. 19 , D. 5 , E. 24 , & D.9, D.12, E.21, E.23, F.11, F.22, F.24, F.25, F.26 \\
\hline VLD & A. 23, B. 8, B. 31, D. 5 , & $\begin{array}{l}\text { A.2, A.7, B.13, B.18, C.6, D.20, E.6, E.7, E.11, E. } 14 \text {, E. } 18 \text {, E. } 21 \text {, F.11, } \\
\text { F. } 24 \text {, F } 25 \text {, F. } 26\end{array}$ \\
\hline LWT & $\begin{array}{l}\text { A. } 3 \text {, А. } 18, \text { А. } 23, \text { B. } 22, \text { B. } 31, \text { B. } 35, \text { C. } 12, \\
\text { C. } 19, \text { E. } 24, \text { F. } 14,\end{array}$ & $\begin{array}{l}\text { A.8, A.9, B. } 39 \text {, D. } 3 \text {, D. } 4 \text {, D. } 8 \text {, D. } 9 \text {, D. } 11 \text {, D. } 12 \text {, D. } 14 \text {, D. } 17 \text {, D. } 24 \text {, D. } 28 \text {, } \\
\text { E. } 9 \text {, E. } 10 \text {, E. } 15 \text {, E. } 17 \text {, E. } 27 \text {, F.15, F. } 22,\end{array}$ \\
\hline PWT & $\begin{array}{l}\text { A. } 3 \text {, А. } 18, \text { A. } 23, \text { B. } 22, \text { B. } 31, \text { B. } 35, \text { C. } 12 \text {, } \\
\text { C. } 19 \text {, E. } 25, \text { F. } 8 \text {, }\end{array}$ & $\begin{array}{l}\text { A.8, A.9, B.39, D.3, D.4, D.8, D.9, D.11, D.12, D.14, D.17, D.24, D. } 28 \text {, } \\
\text { E.9, E.10, E.15, E.17, F.24, F.25, F.26. }\end{array}$ \\
\hline CWT & $\begin{array}{l}\text { A.3, A. } 14, \text { A. } 18, \text { A. } 23, \text { B. } 12, \text { B. } 22, \text { C. } 12, \\
\text { C. } 19 \text {, D. } 15 \text {, D. } 17 \text {, D. } 26, \text { E. } 24, \text { E. } 25 \text {, F. } 8 \text {, } \\
\text { F. } 14\end{array}$ & $\begin{array}{l}\text { A.8, B.39, D.4, D.8, D.9, D.11, D.12, D.14, D. } 24 \text {, D. } 28 \text {, E.9, E. } 15 \text {, } \\
\text { E.17, F.22, F.24, F.25, F.26. }\end{array}$ \\
\hline SHWT & $\begin{array}{l}\text { A. } 3 \text {, A. } 18, \text { A. } 23 \text {, B. } 15, \text { B. } 22, \text { B. } 31, \text { B. } 35 \text {, } \\
\text { C. } 5 \text {, C. } 12 \text {, C. } 19 \text {, D. } 15, \text { D. } 24 \text {, E. } 8, \text { E. } 24, \text { F } .14\end{array}$ & $\begin{array}{l}\text { A.8, B.39, D.4, D.8, D.9, D.11, D.12, D.14, D.17, D. } 28 \text {, E.9, E. } 15 \text {, } \\
\text { E.17, F.11, F.22, F.24, F.25, F.26 }\end{array}$ \\
\hline $\mathrm{SR} \%$ & $\begin{array}{l}\text { А. } 3 \text {, А. } 18, \text { А. } 23, \text { B. } 22, \text { В.31, B. } 35 \text {, С. } 4 \text {, } \\
\text { C.19, E. } 8, \text { E. } 24, \text { F. } 14,\end{array}$ & A.8, D.9, D.12, D.17, D.28, E.9, E.15, E.21, F.11, F.24, F.25, F.26, \\
\hline YLDNO & & A.12, A.14, B.12, B.16, C. 3 , C.25, D.25, D.26, E.25, F.20 \\
\hline YLDWT & $\begin{array}{l}\text { A.3, A. } 18, \text { A. } 23, \text { B. } 15, \text { B. } 31, \text { B. } 35, \text { C. } 4 \text {, } \\
\text { C. } 12, \text { C. } 19, \text { E. } 8, \text { E. } 24, \text { F. } 14\end{array}$ & A.8, B.39, D.8, D.9, D.10, D.11, D.14, D.17, D. 24 , D.28, E. 15 , F.22 \\
\hline
\end{tabular}

result of independent mutation in the different copies of the gene in the presence of a relevant selection pressure. Noli et al. (1997) and Hahn et al. (1995) also observed a higher level of polymorphism in barley and maize, with homologous probes against that realised with RAPD markers.

\section{Genetic diversity}

Genetic similarity estimates based on RFLPs have been shown to be good in accordance with pedigrees in several crops (Smith et al., 1990) and have been used to identify divergent parents for $\mathrm{F}_{1}$ hybrid production (Powel et al., 1996). Reliable estimates of genetic diversity within and between silkworm stocks, as revealed by the RFLP analysis (Powel et al., 1996), are important for the maintenance of germplasm stocks and selection of parents for the development of elite hybrids with higher yield potential.

Earlier studies showed that the number of probes required for generating sufficient number of markers for assessing genetic similarity varies from 15 (Dos Santos et al., 1994) to 100 (Messmer et al., 1993). However, in the present approach substantial numbers of bands were generated with only six probes. The same has been considered as sufficient to estimate genetic similarly as it was projected by Tivang et al. (1994) in maize, that the number of bands required for a $\mathrm{CV}$ of $10 \%$ was 388,150 and 38 for closely, intermediately, and distantly related inbreeds, respectively. Pejic et al. (1998) while using the bootstrap procedure suggested that 150 bands are sufficient for reliable estimates of genetic similarity.

\section{Genetic relationship among silkworm stocks}

As indicated in an earlier paragraph the clustering or grouping on the basis of RFLP marker clearly demarcates the yield potential of 13 silkworm stocks studied. In addition, the closer association between BBI-0044 and BBI0081 is substantiated with the information on the origin of these two breeds, both of which were developed from the commercially available double hybrid of (Kokko $\mathrm{x}$ Seihaku) $\times\left(\mathrm{N}_{124} \times \mathrm{C}_{124}\right)$. The greater distance of BBI0082 from the above two breeds is supported by the fact that the latter was developed from a different Japanese hybrid namely Kinshu x Showa (Chatterjee, 1993). On the other hand, BBI-0095 was developed (Thangavelu et al., 1997) from another Japanese double hybrid $\left[\left(\mathrm{N}_{122} \times\right.\right.$ $\left.\left.\mathrm{C}_{110}\right) \times\left(\mathrm{N}_{124} \times \mathrm{C}_{124}\right)\right]$. However, it is difficult to explain the association of BBE-CHI with BBI-0095. It is possible that sometime during the breeding process a common parent was used to infuse certain specific characters.

With regard to the relationship between the low yielding stocks, certain aspects need to be highlighted. Though BME-0005 is very close to BMI-0017 or BMI0001 with regard to the economic character, they do not occupy close position in the dendrogram. This is not unusual if one considers the origin of these races. BMI- 
TABLE 5. Result of multiple regression analyses (Stepwise method) for identifying significant association between yield components and specific RFLP markers.

\begin{tabular}{|c|c|c|c|c|}
\hline DNA marker & $\mathrm{R}^{2}$ & $\mathrm{R}^{2}$-Change & F-change & $\begin{array}{c}\text { Sig. of } \\
\text { F-change }\end{array}$ \\
\hline \multicolumn{5}{|l|}{ EGGNO } \\
\hline $\mathrm{C} 3$ & 0.572 & ---- & 14.694 & 0.003 \\
\hline +D5 & 0.882 & 0.310 & 26.232 & 0.000 \\
\hline$+\mathrm{F} 14$ & 0.951 & 0.069 & 12.487 & 0.006 \\
\hline \multicolumn{5}{|l|}{ TLD } \\
\hline F24 & 0.543 & --- & 13.094 & 0.004 \\
\hline +D5 & 0.808 & 0.265 & 13.778 & 0.004 \\
\hline$+\mathrm{E} 9$ & 0.946 & 0.138 & 23.114 & 0.001 \\
\hline$+\mathrm{C} 7$ & 0.974 & 0.028 & 8.392 & 0.020 \\
\hline$+\mathrm{E} 27$ & 0.992 & 0.018 & 15.190 & 0.006 \\
\hline$+\mathrm{D} 10$ & 0.999 & 0.007 & 37.813 & 0.001 \\
\hline+ D8 & 1.000 & 0.001 & 11.741 & 0.019 \\
\hline$+\mathrm{A} 9$ & 1.000 & 0.000 & 19.000 & 0.012 \\
\hline \multicolumn{5}{|l|}{ VLD } \\
\hline D5 & 0.494 & ---- & 10.759 & 0.007 \\
\hline$+\mathrm{A} 23$ & 0.847 & 0.353 & 23.098 & 0.001 \\
\hline$+\mathrm{F} 4$ & 0.946 & 0.946 & 16.662 & 0.003 \\
\hline$+\mathrm{E} 17$ & 0.979 & 0.032 & 12.087 & 0.008 \\
\hline$+\mathrm{E} 8$ & 0.992 & 0.013 & 11.334 & 0.012 \\
\hline$+\mathrm{D} 26$ & 0.998 & 0.006 & 18.125 & 0.005 \\
\hline \multicolumn{5}{|l|}{ LWT } \\
\hline A3 & 0.658 & ---- & 21.199 & 0.001 \\
\hline$+\mathrm{B} 17$ & 0.901 & 0.242 & 24.342 & 0.001 \\
\hline$+\mathrm{F} 24$ & 0.969 & 0.069 & 20.119 & 0.002 \\
\hline$+\mathrm{E} 23$ & 0.989 & 0.020 & 14.111 & 0.006 \\
\hline$+\mathrm{C} 19$ & 0.994 & 0.006 & 7.001 & 0.033 \\
\hline \multicolumn{5}{|l|}{ PWT } \\
\hline F14 & 0.625 & ---- & 18.306 & 0.001 \\
\hline$+\mathrm{C} 19$ & 0.912 & 0.287 & 32.575 & 0.000 \\
\hline$+\mathrm{A} 3$ & 0.953 & 0.041 & 7.895 & 0.020 \\
\hline$+\mathrm{A} 14$ & 0.979 & 0.026 & 10.147 & 0.013 \\
\hline \multicolumn{5}{|l|}{ CWT } \\
\hline F14 & 0.630 & ---- & 18.710 & 0.001 \\
\hline$+\mathrm{C} 19$ & 0.930 & 0.301 & 43.193 & 0.000 \\
\hline$+\mathrm{A} 3$ & 0.974 & 0.043 & 14.909 & 0.004 \\
\hline \multicolumn{5}{|l|}{ SHWT } \\
\hline $\mathrm{C} 12$ & 0.624 & ---- & 18.253 & 0.001 \\
\hline$+\mathrm{F} 14$ & 0.881 & 0.257 & 21.689 & 0.001 \\
\hline$+\mathrm{B} 35$ & 0.943 & 0.062 & 9.740 & 0.012 \\
\hline$+\mathrm{B} 35(\mathrm{C} 12 \#)$ & 0.939 & 0.004 & 0.594 & 0.460 \\
\hline$+\mathrm{A} 3$ & 0.970 & 0.031 & 9.372 & 0.014 \\
\hline \multicolumn{5}{|l|}{ SR\% } \\
\hline A 8 & 0.582 & ---- & 15.305 & 0.002 \\
\hline$+\mathrm{F} 14$ & 0.782 & 0.200 & 9.153 & 0.013 \\
\hline$+\mathrm{B} 31$ & 0.902 & 0.121 & 11.091 & 0.009 \\
\hline$+\mathrm{A} 2$ & 0.953 & 0.051 & 8.588 & 0.019 \\
\hline$+\mathrm{D} 17$ & 0.979 & 0.026 & 8.640 & 0.022 \\
\hline \multicolumn{5}{|l|}{ YLDNO } \\
\hline $\mathrm{C} 3$ & 0.738 & ---- & 31.052 & 0.000 \\
\hline$+\mathrm{D} 17$ & 0.899 & 0.161 & 15.878 & 0.003 \\
\hline$+\mathrm{B} 32$ & 0.939 & 0.040 & 5.954 & 0.037 \\
\hline$+\mathrm{E} 23$ & 0.970 & 0.030 & 7.982 & 0.022 \\
\hline \multicolumn{5}{|l|}{ YLDWT } \\
\hline B31 & 0.685 & ---- & 23.957 & 0.000 \\
\hline+ F14 & 0.896 & 0.211 & 20.231 & 0.001 \\
\hline
\end{tabular}

\# C12 was removed from the regression equation at this stage. + indicates markers selected up to the preceding step in the equation.
0017 is a race used on the Gangetic plain for not less than 100 years (Mukherjee, 1912), whereas BMI-0001 is a race used in Southern peninsula where sericulture developed later. Thus, the distance reflected in the dendrogram appears justified. The position of C'Nichi is quite interesting. Chatterjee \& Datta (1992) indicated that this race is a segregant from the original hybrid Shi.Nichi. This hybrid was introduced during early part of the last century (Ghosh, 1949). Other studies in this laboratory (unpublished) also show the presence of DNA markers specific to high cocoon weight and high shell weight in this race, though the expression of high cocoon weight and high shell weight could not be realised.

\section{Association between DNA markers and yield components}

Different groups of scientists have utilized different statistical approaches to ascertain the association(s) between molecular markers and yield attributes. For instance, Barbosa-Neto et al. (1996) and Virk et al. (1996) adopted linear regression, while Lynch (1999) and Yonash et al. (2000) utilized genetic correlation and single band/multiband analysis, respectively.

The correlation analysis enabled us to find 70 RFLP markers showing significant association with ten yield components. Pearson correlation estimates do not take into account the multiple interactions between independent variables on one hand and that between independent and dependent on the other. Multiple regression analysis is a relevant tool in this context, as projected by the "multiband" analysis for establishing linkage between RFLP markers and antibody response in meat-type chickens (Yonash et al., 2000). Virk et al. (1996) also adopted a similar approach in analyzing quantitative variation within rice germplasm using RAPD markers. The application of t-test (Table 6) attests significance to the difference between the two means for all components except EGGNO, thereby strengthening the adoption of MRA for establishing association between DNA markers and yield attributes.

Thus the result obtained creates an opportunity for isolating specific bands for further characterisation of the fragment(s). Moreover, such selected markers can help in marker assisted selection (MAS) program for molecular breeding (Stomberg et al., 1994). The success of such selection programs depends exclusively on the extent of linkage between markers and the relevant loci such as QTLs (quantitative trait loci). This requires further study with the specific markers selected from such analyses.

\section{Abbreviations used}

$\mathrm{BBE}=$ Bombyx bivoltine exotic; $\mathrm{BBI}=$ Bombyx bivoltine indigenous; $\mathrm{BME}=$ Bombyx multivoltine exotic; $\mathrm{BMI}=$ Bombyx multivoltine indigenous; $\mathrm{CHI}=$ Chinese; $\mathrm{CV}=$ coefficient of variance; $\mathrm{EDTA}=$ ethylene diamine tetraacetic acid; EGGNO = mean number of eggs laid by one mother moth; ISSR = inter simple sequence repeat; JAP = Japanese; LWT, PWT, CWT, and SHWT, denote weight of single matured larva, pupa, cocoon, and cocoon shell, respectively; MAS $=$ marker assisted selection; $\mathrm{MRA}=$ multiple regression analysis; ND \& $\mathrm{D}=$ nondiapause and diapause; PHYLIP $=$ phylogeny inference 
TABLE 6. Results of t-test for the difference in the mean values realized from a particular yield component in stocks showing the presence and absence of the band reflected at the first step of MRA.

\begin{tabular}{lccccc}
\hline Parameters & \multirow{2}{*}{ Band selected } & \multicolumn{2}{c}{ Mean and SD of yield components } & \multirow{2}{*}{-value } & \multirow{2}{*}{ Significance } \\
\cline { 3 - 5 } & & Present & Absent & & \\
\hline Egg Number (EGGNO) & $\mathrm{C} 3$ & $413.4 \pm 30.2$ & $502.5 \pm 30.4$ & 12.7 & 0.08 (NS) \\
Total Larval Duration (TLD) & F24* & $602.5 \pm 25.9$ & $558.8 \pm 11.7$ & 2.2 & 0.002 \\
V instar Larval Duration (VLD) & D5 & $150.5 \pm 18.4$ & $196.0 \pm 14.1$ & 4.3 & 0.05 \\
Larval Weight (LWT) & A3 & $22.3 \pm 3.3$ & $32.6 \pm 4.6$ & 2.2 & 0.001 \\
Pupal Weight (PWT) & F14 & $1.0 \pm 0.2$ & $1.4 \pm 0.2$ & 2.6 & 0.01 \\
Cocoon Weight (CWT) & F14 & $1.2 \pm 0.2$ & $1.8 \pm 0.2$ & 2.8 & 0.01 \\
Shell weight (SHWT) & C12* & $27.6 \pm 5.2$ & $16.0 \pm 4.5$ & 2.3 & 0.003 \\
Shell Ratio (SR\%) & A8* & $16.8 \pm 1.6$ & $13.5 \pm 1.0$ & 2.2 & 0.001 \\
Yield Number (YLDNO) & C3* & $7876.3 \pm 397.4$ & $6250.5 \pm 74.2$ & 2.2 & $2.1 \mathrm{e}-07$ \\
Yield Weight (YLDWT) & B31 & $8.7 \pm 1.5$ & $13.8 \pm 2.1$ & 3.2 & 0.03 \\
\hline
\end{tabular}

*Band showing association with higher yield components.

package; QTL = quantitative trait loci; RFLP = restriction fragment length polymorphism; SDS = sodium dodecyl sulphate; $\mathrm{SR} \%=$ ratio of weight of shell to the weight of cocoon; $\mathrm{SSC}=$ saline sodium citrate; TAE $=$ Tris acetic acid; TE $=$ Tris-EDTA; TLD $=$ total larval duration; TRIS $=$ hydroxymethyl-aminomethane; UPGMA = unweighted pair-group method using arithmetic average; VLD = duration of fifth instar; VOLT = voltinism; YLDNO and YLDWT $=$ number of cocoon realized $/ 10,000$ larvae reared and their weight in $\mathrm{kg}$.

ACKNOWLEDGEMENTS. This work was supported, in part, by a grant (No. 2666/95) from the Dept. of Biotechnology, Govt. of India. The financial support of the Dept. of Biotechnology and Central Silk Board is greatly appreciated. The authors thank Mr. C.V. Nair and Mr. P. M. Rajendiran for their assistance in silkworm rearing and maintenance.

\section{REFERENCES}

Barbosa-Neto J.F., Sorrells M. E. \& Cisar G. 1996: Prediction of heterosis in wheat using coefficient of parentage and RFLP-based estimates of genetic relationship. Genome 39: $1142-1149$.

BARK O.H. \& HaveY M.J. 1995: Similarities and relationships among populations of the bulb onions as estimated by nuclear RFLPs. Theor. Appl. Genet. 90: 407-414.

Blanchetot A. 1991: A Musca domestica satellite sequence detects individual polymorphic regions in insect genome. Nucleic Acids Res. 19: 929-932.

Botstein D., White R.L., Skolnick M. \& Davis R.W. 1980 Construction of a genetic map in man using restriction fragment length polymorphisms. Am. J. Human. Genet. 32: 314-331.

Chatterjee S.N. \& Datta R.K. 1992: Hierarchical clustering of 54 races and strains of the mulberry silkworm, Bombyx mori L: Significance of biochemical parameters. Theor. Appl. Genet. 85: 394-402.

ChatterJee S.N. 1993: Silkworm breeding in India. Sericologia 33: $427-447$.

Chatterjee S.N., Rao C.G.P., ChatterJee G. K., Ashwath S. K. \& PatNark A.K. 1993: Correlation between yield and biochemical parameters in the mulberry silkworm, Bombyx mori L. Theor. Appl. Genet. 87: 385-391.

Currie R. 1996: Changing pattern in international demand for silk and silk goods. In Global silk scenario-2001. Proc. Intl.
Conference in Sericulture, 1994. Oxford \& IBH Publ., Calcutta, India, pp. 37-43.

Dos Santos J.B., Nienhuis J., Skroch P., Tivang J. \&. Slocum M. K. 1994: Comparison of RAPD and RFLP genetic markers in determining genetic similarity among Brassica oleracea $\mathrm{L}$. genotypes. Theor. Appl. Genet. 87: 909-915.

Felsenstein J. 1989: PHYLIP-phylogeny inference package (Version 3.2) Cladistics 5: 164-166.

Grosh C.C. 1949: Silk Production and Weaving in India. CSIR Monograph, India, pp. 13-17.

GoldsмiтH M.R. 1991: Silkworm breeding for the "90"s: New molecular and genetic tools to meet the challenge of the tropics. Sericologia 31: 145-155.

Hahn V., Blankenhorn K., Schwall M. \& Melchinger A.E. 1995: Relationships among early European maize inbreds: III. Genetic diversity revealed with RAPD markers and comparison with RFLP and pedigree data. Maydica 40: 299-310.

JeFFreys A.J., Wilson V. \& Thern S.L. 1985: Individual specific "fingerprints" of human DNA. Nature 316: 76-79.

Jefrereys A.J., Royle N.J., Patel I., Armotr J.A.L., MacLeod A., Collic A., Gray I.C., Neumann R., Gibbs M., Crosier M., Hill M., Singer E. \& Monckton D. 1991: Principles and Recent Advances in Human Fingerprinting: Approaches and Applications. Birkhauser Verlag, Basel, pp. 1-19.

Jung C., Pillen K., Frese L., Fahr S. \& Melchinger A.E. 1993: Phylogenetic relationships between cultivated and wild species of the genus Beta revealed by DNA fingerprining. Theor. Appl. Genet. 86: 449-457.

Landry B.S., Kesseli R., Leung H. \& Michaelmore R.W. 1987: Comparison of restriction endonucleases and sources of probes for their efficiency in detecting restriction fragment length polymorphisms in lettuce (Lactuca sativa L.). Theor. Appl. Genet. 74: 646-653.

Lu J., Knox M. R., Ambrose M.J., Brown J.K.M. \& Eluis T.H.N. 1996: Comparative analysis of genetic diversity in pea assessed by RFLP-and PCR-based methods. Theor. Appl. Genet. 93: 1103-1111.

LYNCH M. 1999: Estimating genetic correlations in natural populations. Genet. Res. 74: 255-264.

Messmer M.M., Melchinger A.E., Hermann R.G. \& Boppenmeir J. 1993: Relationship among early European maize inbreds II. Comparison of pedigree and RFLP data. Crop. Sci. 33: 944-950.

Michaelmore R.W., Paran I. \& Kesseli R.V. 1991: Identification of markers linked to disease resistance genes by bulked segregant analysis: a rapid method to detect markers in spe- 
cific genomic regions using segregating populations. Proc. Natl. Acad. Sci. USA 88: 9828-9832.

Miller J.C. \& TANKSLEY S.D. 1990: RFLP analysis of phylogenetic relationships and genetic variation in genus Lycopersicon. Theor. Appl. Genet. 80: 437-448.

Mitra A., Yadav B.R., Ganai N.A. \& Balakrishnan C.R. 1999 Molecular markers and their applications in livestock improvement. Curr. Sci. 77: 1045-1053.

MuKHERJee N.G. 1912: Handbook of Sericulture. Govt. Book Depot, Calcutta, India.

Nagaraja G.M. \& Nagaravu J. 1995: Genome fingerprinting of the silkworm, Bombyx mori, using random arbitrary primers. Electrophoresis 16: 1633-1638.

Nagaraju J., Sharma A., Sethuraman B.N., Rao G.V. \& Singh L. 1995: DNA fingerprinting in silkworm Bombyx mori using banded krait minor satellite DNA - derived probe. Electrophoresis 16: 1639-1642.

NEI M. \& LI W.H. 1979: Mathematical model for studying genetic variation in terms of restriction endonucleases. Proc. Natl. Acad. Sci. U.S.A 76: 5269-5273.

NeuruUsen S.L. 1992: Evaluation of restriction fragment length polymorphism in Cucumis melo. Theor. Appl. Genet. 83: 379-384.

Noli E., Salvi S. \& Tuberosa R. 1997: Comparative analysis of genetic relationships in barley based on RFLP and RAPD markers. Genome 40: 607-616.

O'Brien S.J. 1993: Genetic Maps 6th ed. Cold Spring Harbor Laboratory Press, Cold Spring Harbor, N.Y., pp. 4.1-4.52.

Paterson A.H., Lin Y.R., Li Z., Schertz K.F. \& Dobbley J.F 1995: Convergent domestication of cereal crops by independent mutation at corresponding genetic loci. Science $\mathbf{2 6 9}$ : $1714-1718$

Paull J.G., Chalmers K.J., Karakousis A., Kretsehmer J.M., Manning S. \& Langridge P. 1998: Genetic diversity in Australian wheat varieties and breeding material based on RFLP data. Theor. Appl. Genet. 96: 435-446.

Pejic I., Marsan P.A., Morgante M., Kozumplik V., Castiglioni P., Taramino G. \& Motto M. 1998: Comparative analysis of genetic similarity among maize inbred lines detected by RFLPs, RAPDs, SSRs, and AFLPs. Theor. Appl. Genet. 97: $1248-1255$

Powel W., Morgante M., Andre C., Hanafey M., Vogel J., TINGEY S. \& RAFALSKI A. 1996: The comparison of RFLP, RAPD, AFLP and SSR (microsatellite) markers for germplasm analysis. Mol. Breed. 2: 225-238.

Reddy K.D., Abraham E.G. \& Nagaramu J. 1999a: Microsatellites in the silkworm, Bombyx mori: Abundance, polymorphism, and strain characterization. Genome 42: 1057-1065.

Reddy K.D., Abraham E.G. \& Nagaraju J. 1999b: Genetic characterisation of silkworm, Bombyx mori by simple sequence repeat (SSR)-anchored PCR. Heredity 83: 681-687.
Salimath S.S., de Oliveira A.C., Godwin I.D. \& Bennetzen J.L. 1995: Assessment of genome origins and genetic diversity in the genus Eleusine with DNA markers. Genome 38: 757-763.

SAMBrooK J., Fritsch E.F. \& Maniatis T. 1989: Molecular Cloning: A Laboratory Manual. Cold Spring Harbor Laboratory Press, Cold spring Harbor, N.Y.

Shi J., HeCkel D.G. \& Goldsmith M.R. 1995: A genetic linkage map for the domesticated silkworm, Bombyx mori, based on Restriction Length Polymorphisms. Genet. Res., Camb. 66: 109-126.

Smith O.S., Smith J.S.C., Bowen S.L., Tenborg R.A. \& Wall S.J. 1990: Similarities among a group of elite maize inbreds as measured by pedigree, $\mathrm{F}_{1}$ heterosis, and RFLPs. Theor. Appl. Genet. 80: 833-840.

Song K., Osborne T.C. \& Williams P.H. 1990: Brassica taxonomy based on nuclear restriction fragment length polymorphisms (RFLPs). 3. Genome relationships in Brassica and related genera and the origin of B. oleracea and B. rapa (syn. Campestris). Theor. Appl. Genet. 79: 497-505.

Stomberg L.D., Dudley J.W. \& Rufener G.K. 1994: Comparing conventional early generation selection with molecular marker assisted selection in Maize. Crop Sci. 34: 1221-1225.

Sulaman I.M., Ehtesham N.Z. \& Hasnain S.E. 1995: A multicopy DNA sequence from Meconopsis simplicifolia discriminates between the different species of this endangered Himalayan poppy. Gene 156: 223-227.

Tanksley S.D., Ganal M.W., Prince J.P., Dvicente M.C. \& Bonierbale M.N. 1992: High diversity molecular linkage maps of tomato and potato genomes. Genetics 132: 1141-1160.

Tanksley S.D., Young N.D., Paterson A.H. \& Bonierbale M.W. 1989: RFLP mapping in plant breeding: New tools for an old science. Biotechnol. 7: 257-264.

Thangavelu K., Mukherjee P., Sinha R.K., Mahadevamurthy T.S., Sunitha M., Sahni N.K., Kumaresan P., Rajarajan P.A., Mohan B. \& SeKar S. 1997: Catalogue on Silkworm (Bombyx mori L.) Germplasm Vol. 1. Silkworm and Mulberry Germplasm Station, Hosur, Tamil Nadu, India, pp. 79-138.

Trvang J.G., Nienniuis J. \& Smith O. 1994: Estimation of sampling variance of molecular marker data using the boot strap procedure. Theor. Appl. Genet. 89: 259-264.

Vtrk P.S., Ford-Lloyd B.V., Jackson M.T., Poon H.S., CleMeNO T.P. \& Newbury H.J. 1996: Predicting quantitative variation within rice germplasm using molecular markers. Heredity 76: 296-304.

Yonash N., Heller E.D., Hillel J. \& Cahanar A. 2000: Detection of markers associated with antibody response in meattype chickens: Haplotype/genotype, single-band, and multiband analyses of RFLP in the major histocompatibility complex. J. Heredity 91: 24-30. 